\title{
Drip irrigated Barley (Hordeum vulgare L.) in arid regions of South Tunisia: Plant Growth and Yield Parameters
}

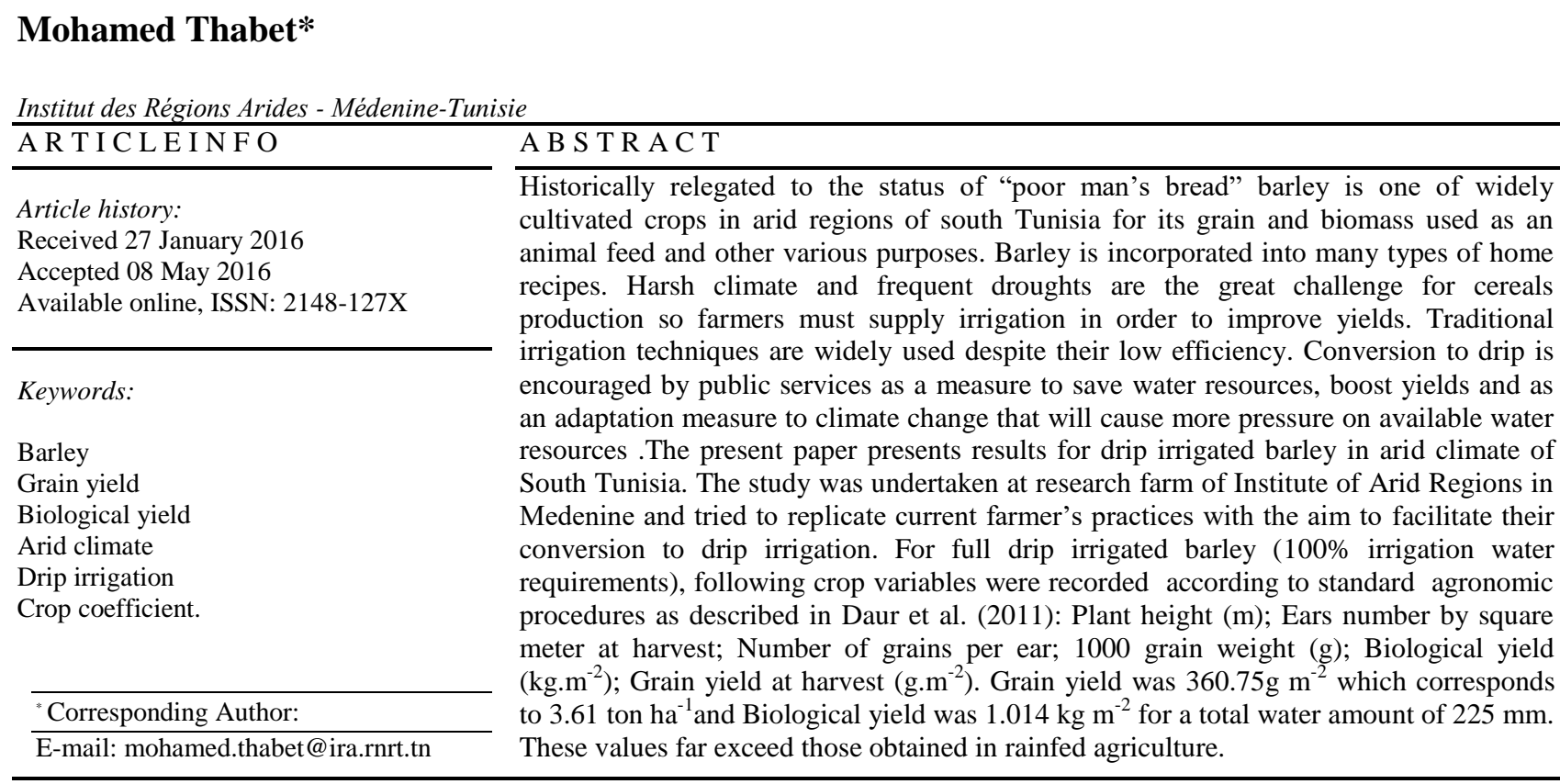

\section{Introduction}

As many countries of Mediterranean basin, water is a scarce source in Tunisia because of harsh climate and frequent droughts. Competition for this source between agricultural, industrial and urban consumers increases continually (Romagny et al., 2004). The arid climate requires that cultivated crops be irrigated. Under these conditions of scarcity, crop production must be maintained at expense of minimum inputs but aiming at achieving maximum incomes. As irrigated agriculture is dominated by traditional methods of surface irrigation (Thabet, 1997), drip irrigation is considered as one of the most effective methods to supply water to crops (Sermet et al., 2005). It can result in water saving if good management procedures are applied (Ünlü et al., 2006). As it was one of the most important food grains from ancient times until the beginning of the twentieth century, current practices in the arid regions of Tunisia give to barely (Hordeum vulgare L.) an important place in winter annual crops rotations (Nagaz et al., 2010). Millet (Pennisetum glaucum) is cultivated as a summer crop. These two cereals are characterized by short cycle and high economic value. Barely cycle coincides with the rainy season but great variability in rainfall due to climate change has made so difficult to grow it and must be irrigated. Barley is considered as one of more tolerant crops to salinity. It is cultivated around shallow wells of the region that most part has a TDS around $5 \mathrm{~g} / \mathrm{L}$. Largest used irrigation systems for barely are basin and border irrigation, they need important volumes of water due to their low efficiency because of leveling difficulties and high sand fraction of soil that promotes seepage losses. Conversion to drip irrigation is a national strategy to save water in order to extend irrigated areas. Nevertheless, this technique relatively recent is widely used for row crops and fruit tree but not for cereals and some other field crops. The aim of this paper is to study possibility and yield of drip irrigated barley in arid climate of south Tunisia

\section{Materials and Methods}

\section{Experimental Site and Layout}

Experiment was carried out at research farm of Arid

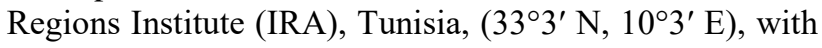
$100 \mathrm{~m}$ altitude. Climate is typically Mediterranean with dry and hot summer and irregularly distributed precipitations throughout the year. Principles weather parameters are included in Table 1

Soil at experimental farm is loamy sand and almost flat. Before seeding, it was ploughed; levelled and 40 units per hectare of $\mathrm{K}_{2} \mathrm{O}$ and $\mathrm{P}_{2} \mathrm{O}_{5}$ were applied as basic fertilizer. For nitrogen (ammonitrate 33.5\%) 60 units were 
applied at seed emergence, 70 units at the beginning of heading and 70 units late heading. Soil texture of trial plots is dominated by sand that exceeds $80 \%$.

Experimental layout is shown in figure1. It is a small plot of $120 \mathrm{~m}^{2}$ area divided into 10 small strips of 1 meter wide on 12 meters length each one and drip irrigated from a shallow well. Measurements have been taken in strips 2, 5 and 9 which represent the head, the middle and the end of the plot in order to see both spatial variability and avoid side effects. Strips dimensions are those most frequently encountered in smallholder farming in the region. Each strip is equipped with two laterals in low density polyethylene plastics pipes of $16 \mathrm{~mm}$ diameter for drippers. The spacing between the lateral lines was $0.5 \mathrm{~m}$ and drippers were mounted on lateral lines at $0.5 \mathrm{~m}$ spacing. Chosen strips for this trial were considered as three replications (R1, R2 and R3). Sowing was done by broadcast seeding method as in smallholder farming in the region with a rate of 12 grams by square meter on November $26^{\text {th }} 2012$.

Irrigation water was pumped from the shallow well at a pressure of $10 \mathrm{~m}$ achieved by discharge controlling valve. Principles irrigation water characteristics are:

$$
\begin{aligned}
& \mathrm{pH}=7.9 ; \\
& \mathrm{SAR}=10.8 ;
\end{aligned}
$$

Electrical Conductivity $(\mathrm{EC})=4.6 \mathrm{dS} / \mathrm{m}$.

\section{Crop Water Requirements}

Water requirement (ETc) values are useful for effective planning of irrigation scheduling. ETc values were obtained by using ETo and Kc values according to Doorenbos and Pruit (1977) and Allen et al. (1998) procedures. Crop evapotranspiration (ETc) is linked to reference evapotranspiration (ETo) by kc factor which increases with crop growing season by The following equation:

$$
\mathrm{ETc}=\mathrm{Kc} \times \mathrm{ETo}
$$

Based on Kc values, entire cropping period is divided into four growth stages: initial, development, mid and maturity. Barley crop growing periods were considered 120 days divided into 15 days, 25 days, 50days and 30days respectively for growing stages in climatic conditions of study area.

For different crop stages of Barley (local landrace: Ardaoui), Kc values are respectively: $0.3 ; 0.7 ; 1.15$ and 0.4 .

\section{Irrigation Scheduling}

Calculations performed according equation (1) lead to irrigation scheduling calendar shown in Table 2.

Used drippers flow in the experiment was four liters per hour $\left(4 \mathrm{~L} \cdot \mathrm{h}^{-1}\right)$.One liter delivered by the dripper corresponds to $4 \mathrm{~mm}$ amount of water at the field since each drip irrigates an area of $50 \mathrm{~cm} \times 50 \mathrm{~cm}$.

\section{Results and Discussion}

As strip areas are very small most of the measures were performed exhaustively. For the number of grains per ear, five ears were collected at each strip at head, middle and the end. Presented data correspond to the average in each strip.

Table 1 Local weather parameters

\begin{tabular}{l|ccccccc}
\hline Month & $\begin{array}{c}\text { Rainfall(mean) } \\
(\mathrm{mm} / \text { month) }\end{array}$ & $\begin{array}{c}\text { Rain } \\
(\text { days/month) }\end{array}$ & $\begin{array}{c}\text { Mean temp } \\
\left({ }^{\circ} \mathrm{C}\right)\end{array}$ & $\begin{array}{c}\text { RH } \\
(\%)\end{array}$ & $\begin{array}{c}\text { Sunshine } \\
(\% \text { of Hrs })\end{array}$ & $\begin{array}{c}\text { WS } \\
(\mathrm{m} / \mathrm{s})\end{array}$ & $\begin{array}{c}\text { Penman-Monteith ETo } \\
(\mathrm{mm} / \text { day })\end{array}$ \\
\hline Jan & 17 & 3.60 & 11.80 & 64.00 & 69.00 & 3.80 & 2.31 \\
Feb & 18 & 2.90 & 13.40 & 62.00 & 71.00 & 3.90 & 2.98 \\
Mar & 29 & 3.70 & 15.40 & 62.00 & 69.00 & 4.10 & 3.76 \\
Apr & 15 & 2.80 & 18.40 & 62.00 & 70.00 & 4.40 & 4.79 \\
May & 6 & 2.10 & 22.00 & 63.00 & 73.00 & 4.30 & 5.73 \\
Jun & 2 & 1.10 & 25.70 & 63.00 & 76.00 & 4.10 & 6.57 \\
Jul & 0.3 & 0.40 & 27.90 & 60.00 & 85.00 & 3.80 & 7.25 \\
Aug & 1 & 0.50 & 28.70 & 63.00 & 85.00 & 3.70 & 6.76 \\
Sep & 8 & 1.80 & 26.30 & 65.00 & 75.00 & 3.70 & 5.33 \\
Oct & 21 & 3.30 & 22.30 & 64.00 & 73.00 & 3.50 & 3.99 \\
Nov & 18 & 3.70 & 16.80 & 63.00 & 72.00 & 3.30 & 2.80 \\
Dec & 17 & 3.70 & 12.80 & 66.00 & 69.00 & 3.70 & 2.19 \\
\hline
\end{tabular}

Table 2 Irrigation scheduling calendar

\begin{tabular}{l|cccc}
\hline \multicolumn{1}{c|}{ Stage } & 1 & 2 & 3 & 4 \\
\hline Length (days) & 15 & 25 & 50 & 30 \\
Kc & 0.3 & 0.7 & 1.15 & 0.4 \\
ETc (mm) & 10 & 35 & 137 & 44 \\
Irrigations & 2 & 3 & 8 & 3 \\
Irrigation rate (mm) & 5 & 12 & 16 & 15 \\
\hline
\end{tabular}




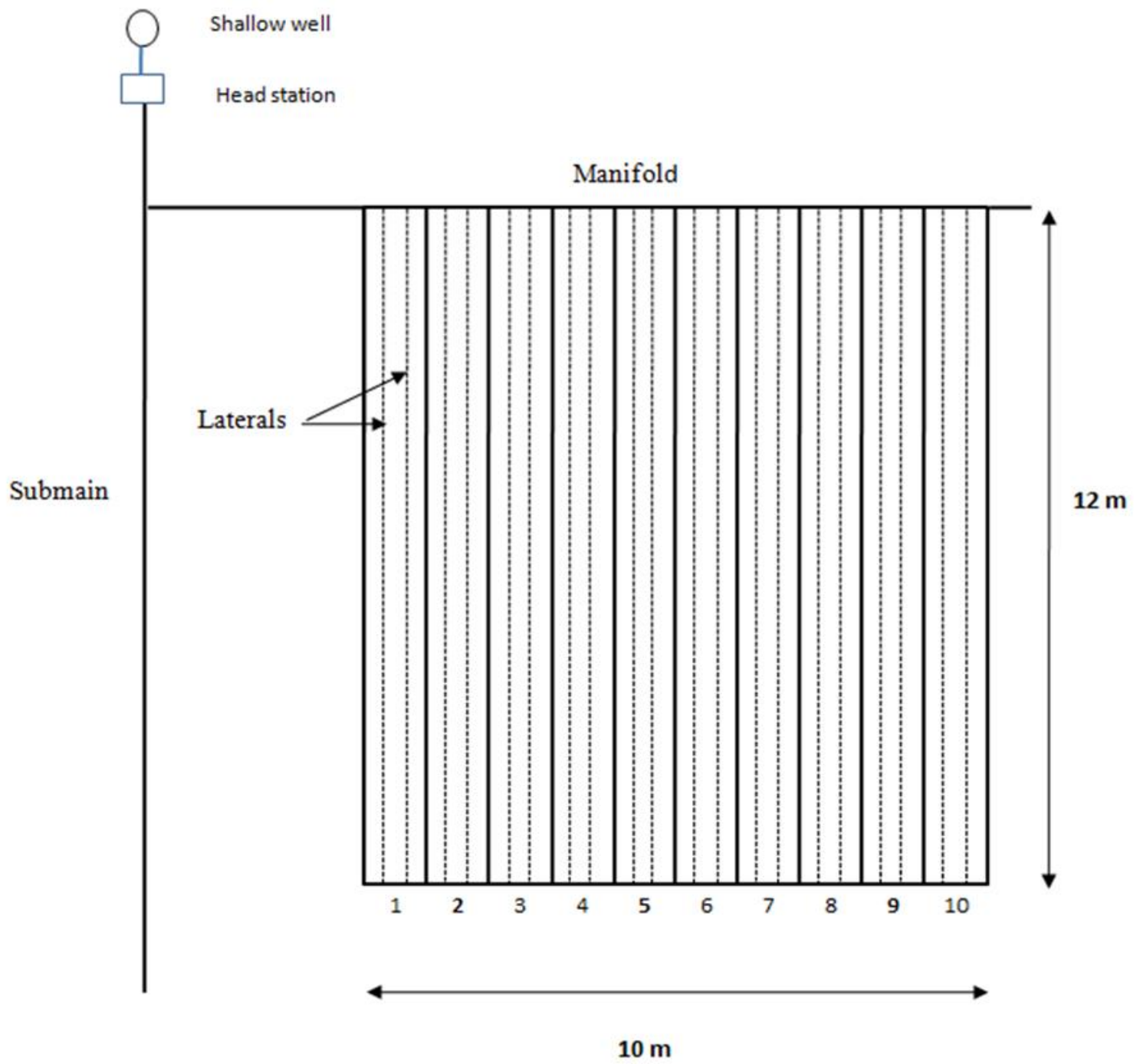

Figure 1 experimental layout components

\section{Plant Height $(m)$}

Plant height depends on both varieties, water availability, mineral and organic fertilization. Height directly affects biological yield. At harvest, plants height measured between $0.98 \mathrm{~m}$ and $1.14 \mathrm{~m}$ as shown in figure 2 whereas it was 32.8 and 45.6 for Almarshadi and Ismail (2014).

In varietal study of 13 genotypes of barley in Algeria, Souilah (2012) has obtained heights from $0.81 \mathrm{~m}$ to $1.11 \mathrm{~m}$ which agree obtained results. This factor boost biological yield which is an important factor for making some handicraft products and construction of groves shade for animals.

\section{Ears Number $/ \mathrm{m}^{2}$}

The number of ears directly affects yield. More is the number of ears per square meter important more is the yield because for cereals, yield is usually expressed as a product of grains number by grain mass. Results at harvest are shown in figure 3. Average number of ears for all replications is 357.3 ears $\mathrm{m}^{-2}$. Khlouj (2011) has recorded a number of 380.85 ears $\mathrm{m}^{-2}$. Souilah (2012) reported a number of ears per square meter from 102.88 to 344.65 . However, this number depends on seedling density and other environmental factors. Sampling method can affect this number, in our case, measurements were made on complete strip while many others are based on plots of one square meter considered as representative for all field.

\section{Grains Number per Ear}

This factor is an important component of yield. As it was not possible to measure it exhaustively, measurements have been carried out on a sample of five ears taken at the head, the middle and the end of each strip. Measurements average is presented in figure 4. For Souilah study (2012) the number of grains per ear varied from 23.2 to 40.60. However, this number depends on many factors such as water, fertilizing, sowing date ... etc. Productivity depends not only on grain number but also on grain weight. We note that there is no significant difference between different values. However, these values may be influenced by the choice of the experimenter and the variability in the field. 


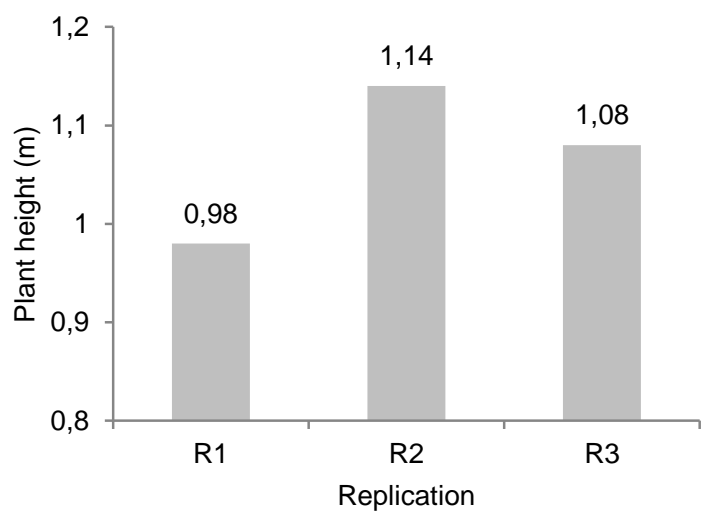

Figure 2 Plant height

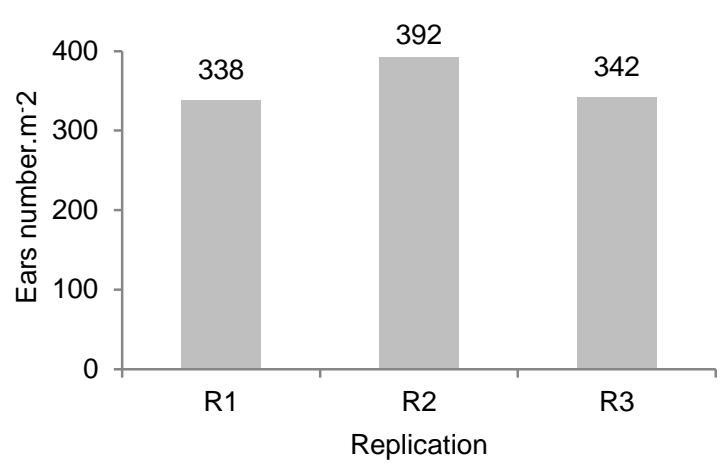

Figure 3 Ears number per square meter

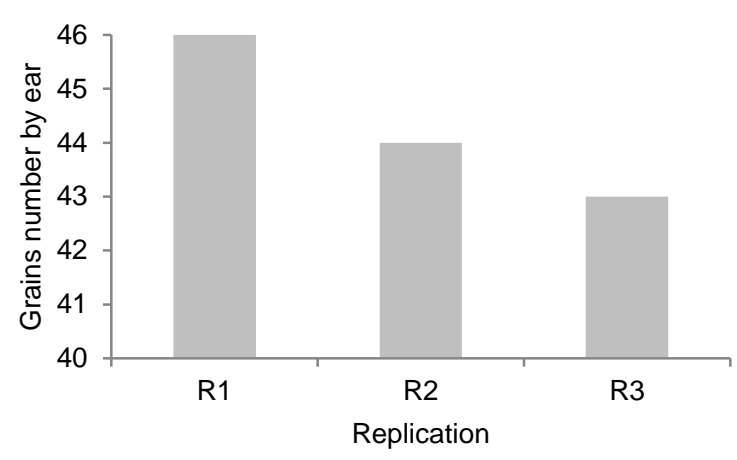

Figure 4 Grain number per ear at harvest

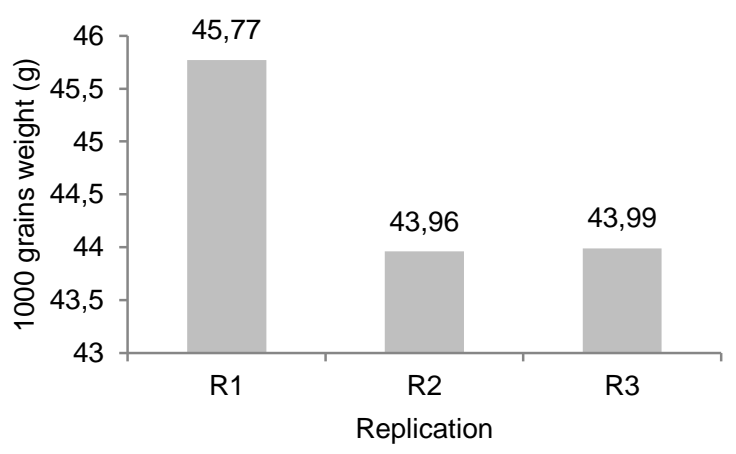

Figure 5 1000grains weight at harvest

\section{Grains Weight $(g)$}

In cereals, 1000-grain weight $(\mathrm{g})$ is a parameter which describes the ability of the accumulation of reserve substances in optimum conditions. Grain filling is done primarily by the recently photosynthesized assimilates. This parameter can be influenced by weather conditions. Knowing the mass of 1000 grains of a cereal sample provides to farmers important information for more accurately calculation of seeds doses needed to meet desired yield. Results of 1000-grain weight at harvest for different replications are shown in figure 5. However, these values may be influenced by the choice of the experimenter and the variability in the field.

Almarshadi and Ismail (2014) given a 1000 grains weight around 34g, for Khlouj (2011) that weight was 52g. Souilah (2012) indicates in her study values of 1000 grains weight going from 34.8 to $61 \mathrm{~g}$. Banga and al (2012) indicates values from 37 to $42 \mathrm{~g}$ for a study undertaken in north Tunisia. Ouji (2010) in the same region obtained values from 36.4 to $48.4 \mathrm{~g}$ as weight of 1000 grains. These results are near from those obtained in our experiment undertaken in other arid part of the country. In France, " C.R.E.A.B " (2008) values of 1000 gains weight go from 43.2 to $52.9 \mathrm{~g}$. This parameter is influenced by many factors as other yield parameters.

\section{Grain Yield $\left(\right.$ g. $\left.\mathrm{m}^{-2}\right)$}

As for all crops, barley yield depends on inputs (water, fertilizers) but also on environmental conditions as tillage and weeding. Results of grain yield in figure 6 expressed in gr. $\mathrm{m}^{-2}$ revealed the same trend as in biological yield. Converted to tons per hectare, mean of this yield corresponds to 3.61 ton ha ${ }^{-1}$. For the Almarshadi and Ismail (2014), grain yield was 3.235 ton ha ${ }^{-1}$ for full irrigated barley. Khlouj (2011) obtained a yield of 3.224 ton $\mathrm{ha}^{-1}$ for barley irrigated with salt water in the same geographical area. All these values exceed those of rainfed barley yield which varies from 0.4 to $1.5 \mathrm{~T} / \mathrm{ha}$ depending on rainfall and its distribution during crop stages (Bachta, 2011).

\section{Biological Yield $\left(\mathrm{kg}^{\mathrm{m}} \mathrm{m}^{-2}\right)$}

Biological yield which is a very important factor is shown in figure 7. Grains serve for nutrition of both human and livestock. During drought periods, straws are very useful in smallholder farming systems for small ruminant's nutrition. Straws are also used by farmers to make huts for shading in rural areas and rangelands.

Difference in biological yield between different replications is not very important. Seeding and fertilizers applications had done by hand; they can be with other environmental factors a source of this little nonuniformity. Almarshadi and Ismail (2014) obtained a biological yield of $0.62 \mathrm{~kg}$ per square meter for full irrigated barley in conditions of Arabia Saudi. To compare variability of different parameters, coefficient of variation $(\mathrm{CV})$ was used.This coefficient represents the ratio of the standard deviation to the mean is a useful statistic for comparing the degree of variation from one data series to another. It is expressed as following: 


$$
\mathrm{CV}=\frac{\text { Standard Deviation }}{\text { Average }}
$$

It is usually expressed in \%. Applied to data of different replications, results are reported in Table 3.

Table 3 Coefficient of variation (CV) of different measured parameters

\begin{tabular}{l|c}
\hline \multicolumn{1}{c|}{ Data series } & CV (\%) \\
\hline Grain number per ear at harvest & 3.4 \\
Ears number per square meter at harvest & 8.4 \\
Grain yield at harvest & 9.4 \\
Biological yield at harvest & 11.2 \\
1000-grain weight at harvest & 3.9 \\
Plant height & 7.5 \\
\hline
\end{tabular}

Excepted Biological yield at harvest, all other values are in a range less than $10 \%$. According to Martin and Gendron (2004) a coefficient of variation between $0.0 \%$ and $16.0 \%$ indicate a little variation in the sample; between $16.0 \%$ and $33.3 \%$, the change is significant; finally, beyond $33.3 \%$ variation is very high. This shows that obtained results in different replications are homogeneous.

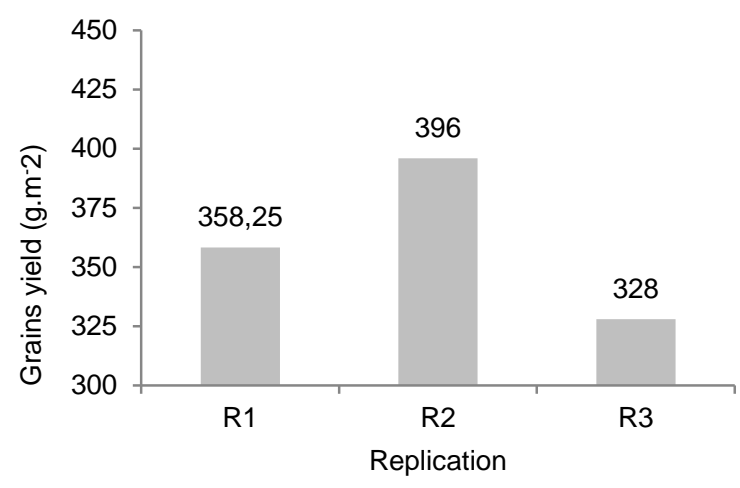

Figure 6 Grain yield at harvest

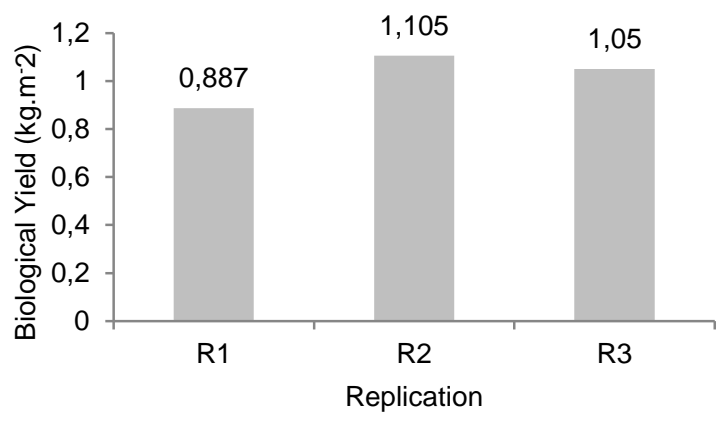

Figure 7 Biological yield at harvest

\section{Conclusions}

The water resources scarcity in Tunisia will be even more pronounced in the coming years which will be affected by climate change, so it is necessary to develop methods and forms of adaptations in future planning and management of water resources. This effort must be linked to the role of scientific research and its multidisciplinary input.

With drip irrigation, generally, only a portion of irrigated area is wetted (cases of row crops and trees). In case of field crops, the network must be relatively dense for covering all plants and this leads to large quantities of water to meet crop needs .Lines spacing can be optimized according to the moistened strip created with each line. Thabet (2008) showed that for a similar soil, this strip ranges from 70 to $80 \mathrm{~cm}$ for drippers flowing 4 liters per hour.

As in this arid climate, barley is generally grown in small areas under rained conditions or with supplemental irrigation; so it will be possible to apply deficit irrigation in the form of Regulated Deficit Irrigation "RDI" or "PRD" 'Partial Rooting Drying (FAO,2002) as this species is known for its tolerance to drought. In all these cases, ratio yields/used water must be optimized for a good water resources management. Drip irrigation also allows reduction in labor and a good uniformity repartition of fertilizers for maximum farmers' profit.

\section{References}

Allen RG, Pereira LS, Raes D, Smith M. 1998. Crop evapotranspiration. Guidelines for Computing Crop Water Requirements, Irrigation and Drainage Paper 56. FAO, Rome, Italy.

Almarshadi MS, Ismail SM. 2014. Barley growth and productivity as affect ted by soil amendments under fully and minimum irrigation conditions in Saudi Arabia. Life Sci J 2014; 11(4):223-230.

Bachta MS. 2011. La céréaliculture en Tunisie Une politique de régulation à repenser. Les notes d'analyse du CIHEAM N 64 .

Banga Kalala JP, Albouchi A, Bouzaien G, Nasr Z, Tshibangu KWT. 2012. Rendement agronomique du blé et de l'orge dans les parcelles associées des jeunes pacaniers à Sidi Mbarek au nord de la Tunisie. TROPICULTURA, 2012, 30, 2, 72-78.

C.R.E.A.B. Midi-Pyrénées: Résultats de l'essai variétés d'orge d'hiver 2007-2008.

Daur I, Sepetoglu H, Sindel B. 2011. Dynamics of faba bean growth and nutrient uptake and their rrelation with grain yield. Journal of Plant Nutrition. 34: 1360-1371.

Doorenbos J, Pruitt WO. 1977. Crop water requirements: guidelines for predicting crop water requirements. FAO irrigation and drainage paper 24, FAO Rome, United Nations.

FAO. 2002. Déficit irrigation practices. Water report 22.

Khadija K. 2011. Pilotage de l'irrigation à l'eau salée et besoins en eau de l'orge en milieu aride. Mastère Lutte Contre la Désertification et Gestion Durable des Ressources en Milieu Aride. Institut National Agronomique de Tunisie.

Martin L, Gendron A. 2004. Méthodes statistiques appliquées à la psychologie. Traitement des données avec Excel (avec CDRom) ISBN: 9782890941465

Nabila S. 2009. Diversité de 13 génotypes d'orge (Hordeum vulgare L.) et de 13 génotypes de blé tendre (Triticum aestivum L.): Etude des caractères de production et d'adaptation. Magister en biologie végétale. Université de Mentouri de Constantine. Faculté de sciences, de la nature et de la vie. Département de biologie et écologie.

Nagaz K, Masmoudi MM, Ben Mechlia N. 2010. Millet Production under Different Irrigation Strategies with Saline Water in Arid Conditions of Tunisia. Res. J.Soil Water Manage., 1(1): 15-20.

Ouji A, Rouaissi et M, Ben Salem M. 2010. Comportement variétal de l'orge (Hordeum vulgare L.) en double exploitation. Annales de l'INRAT, 2010, 83 ,103-114. 
Romagny B, Guillaume H. Ben Ouezdou Hédi, Palluault S. 2004. Ressources en eau, usages et concurrences dans la Djeffara tunisienne. Série Usages, appropriation, gestion des écosystèmes. Documents de recherche $\mathrm{n}^{\circ} 1$. Laboratoire Population - Environnement-Développement, Unité Mixte de Recherche IRD - Université de Provence.
Thabet M. 2008. Etude de l'irrigation goutte à goutte en milieu aride: impacts sur la salinisation du sol et sur une culture de piment (Capsicum Annum L). Thèse de doctorat en sciences agronomiques de l'Institut National Agronomique de Tunisie. 114 pages + annexes.

Ünlü M, Kanber R, Şenyigit U, Onaran H, Diker K. 2006. Trickle and sprinklerrrigation of potato (Solanum tuberosum L.) in the Middle Anatolian Region in Turkey.Agri. Water Manage., 79: 43-71. 